\title{
Removing Some Harm from the World Trade Organization
}

\author{
WILLIAM KINGSTON*
}

ABSTRACT Poor countries were induced to enact the strong intellectual property rights required for membership of the World Trade Organization by empty promises of better access to markets and reductions in US farm and EU export subsidies. Patents have prevented access to cheap generic versions of drugs which such countries badly need, such as for the HIVIAIDS pandemic. Registered Trade Mark protection could be equally serious in future, as this will enable tobacco firms to build up their brands through mass advertising. This must cause rapid growth in related diseases. One palliative could be to use some aid funding to buy in the intellectual property of western firms in these countries. In the drugs case, this would allow development of local capacity to produce inexpensive copies, without diminishing global investment in REDD. Success in this could lead to allocation of the much larger amounts that would be needed to extinguish tobacco branding.

\section{Introduction}

In the most influential article on economics ever written by a biologist, Garret Hardin (1968) showed how "freedom in a commons brings ruin to all". His illustration is a pasture that is not unlimited in size, to which a number of herdsmen, each owning his own flock, have free access. It is in the interest of any herdsman to add more animals to his herd, because the benefit of all their milk, meat and hides will be his alone, whereas their cost, which is the extra consumption of the pasture, will be spread over all his fellows. But what is true for one is equally true for all, with the inevitable result that the pasture will be over-grazed and destroyed. As the sea fisheries of the world disappear at the alarming rate recounted by Myers \& Worm (2003) in Nature, for example, precisely because they have been a commons, it is impossible to doubt the fundamental validity of Hardin's argument.

The solution is to be found in property rights, which can be communal or individual. Under certain stringent social conditions, communal property rights can enable the worst outcome to be avoided in small local areas (see Ostrom, 1990). However, individual property rights have a much wider range of application and are correspondingly more effective. These ensure that self-interest, instead of being harmful to a resource, will: (a) preserve it from the over-use that is inevitable if it remains a commons; and (b) make innovation possible, because it now pays each owner to learn

\footnotetext{
*William Kingston, School of Business Studies, Trinity College, Dublin, Ireland.

The author is grateful to Geoff Tansey for his valuable comments on an earlier draft, and to two anonymous reviewers for constructive criticism and suggestions.
} 
how to do things better and also to do new things with his property. Individual property rights, in fact, can civilize self-interest by forcing us, in following our own goals, to serve the public good also. A necessary condition for this is that the use of individual property is made responsible to the laws which express the basic values that hold a society together. However, the fruitful harmony between private interest and public good which property rights can deliver is inherently unstable. It does not take long for those who are being forced to respond to the public interest in what they own and how they use it to see how to escape the constraints that irk them. This is to get control of the property laws so as to shape them to suit their own special interests. Such laws are always under threat of corruption in this way, so that John Stuart Mill (1862) could rightly note that they "have never yet conformed to the principles on which the institution of private property rests".

The ability of property-owners to influence legislation has accelerated enormously in the last century, a trend which was noted as long ago as 1962 by Buchanan and Tullock in their famous book The Calculus of Consent:

We may observe a notable expansion in the range and extent of collective activity over the last half-century-especially in that category of activity appropriately classified as differential or discriminatory legislation. During the same period we have witnessed also a great increase in investment in organized interest-group efforts designed specifically to secure political advantage.

(Buchanan \& Tullock, 1962, p. 269)

Since they wrote, the expenses of politics have grown at what looks like an exponential rate in every democratic country. In particular, the coming of television has escalated the costs of getting elected, making politicians correspondingly vulnerable to those who will underwrite those costs (see Newman, 1999). Hence the size and dynamism of the contemporary lobbying industry, and the quite new kinds of property, as well as strengthening of older kinds, that have been brought into being through its efforts. Many of these new rights extend the value of ownership of shares in corporations or limited partnerships (see Korten, 1995), but in recent years particular attention has been paid to intellectual property.

\section{Intellectual Property}

In this field, the capture of law-making by private interests can be seen clearly in the United States Patent Act of 1952. The previous legislation dated from 1870, and did not suit the new methods of research needed for antibiotics (for background, see Kingston, 2000). On behalf of their pharmaceutical industry clients, New York Patent Bar Association members drafted a Bill and were able to get it introduced in Congress, and this, supplemented by other Bills and pressures, brought about the changes they wanted. As a judge who, as a patent attorney, had been the main drafter of the legislation wrote later, "The Patent Act was written basically by patent lawyers ... A good $95 \%$ of the members [of Congress] never knew that the legislation was under consideration, or that it had passed, let alone what it contained" (Rich, 1978).

Continued pressure of interests on the shaping of intellectual property law in the USA led to further developments, of which the establishment of the Court of Appeals for the Federal Circuit in 1982 was perhaps the most important. From then onwards, all patent appeals have been dealt with by this Court, and it has shown itself markedly favourable to patent-owners. During this period, these interests focused on getting 
more advantageous law for themselves within the USA; it was the manufacturing industries that were most concerned with getting the laws of other countries changed in their favour. They were behind the thrust towards globalization of property laws and rights which started soon after World War II.

\section{Globalization}

The USA had come out of that war with an ability to produce physical goods beyond anything ever seen before, and consequently wanted the widest possible markets to take advantage of this. Every country had tried to cope with the great depression of the 1930 s by erecting trade barriers, so the USA took the initiative at Bretton Woods in 1944 for the setting up of an international trade organization (ITO) to foster international free trade. This reached the stage of being drafted in the "Havana Charter", but at the time the US Congress was not as much under the influence of business interests as it later became, and vetoed it on sovereignty grounds. The General Agreement on Tariffs and Trade (GATT, which had no members, only "contracting parties") was then set up as a second-best approach to the same free trade objective, in 1948. In spite of lacking the powers which had been envisaged for the ITO, the GATT was very successful in opening up access to world markets for many kinds of manufactured goods, over a series of "rounds" of tariff and quota reductions.

It was easy for the USA to lead this process as long as its own dominance in manufacturing capability persisted; but with the astonishing and unforeseen emergence of similar and even greater capability in the Far East, first in Japan, then in countries like Taiwan and South Korea, US manufacturing industry became highly vulnerable, even leading to rustbelts in its home market. Parallel with this, other US industries, such as those of entertainment and information processing, were the victims of wholesale copying, especially from countries such as Hong Kong, Singapore and China. The interests of manufacturers and of those whose primary interest was in intellectual property therefore converged.

\section{US Retaliation}

The first indication of this was the "Section 301" amendment to the Trade Act of the United States in 1984. This allowed trade sanctions to be imposed on any country which did not provide intellectual property protection for US firms. It was quickly used against Brazil, Colombia, South Korea and some Middle- and Far-Eastern countries. Another version of retaliation was used after litigation about copying of Apple Computer's operating system by Franklin, a Japanese firm. The US 1984 Semiconductor Chip Protection Act was then brought in to prevent any repetition of this. It provides copyright protection, and this needed nothing more than an amendment to the Copyright Act. However, delivering protection in this way would mean that foreign (specifically, of course, Japanese) firms could also benefit from the new protection through the national treatment provision of the Universal Copyright Convention. Instead, by passing a quite separate Act, it was possible to include a condition that its benefit could only be obtained by citizens of states which passed similar legislation to protect US chip producers.

Significantly, Japan complied within a year, and it was quite clear that without this requirement in the Semiconductor Chip Protection Act, it would happily have accepted the new protection for its firms in the USA and done nothing in return. This was another piece of confirmation for the US authorities of the potential value to them of 
requirements for reciprocity, imposed outside the existing institutional framework of the conventions and the GATT.

Consequently, by the time one of the routine revisions of the GATT began with a ministerial conference in Punta del Este in 1986 (the Uruguay Round), US interests were ready as well as determined to use the negotiations to get a world-wide settlement that suited them. Those concerned with intellectual property were especially well organized for bringing pressure to bear (see Drahos \& Braithwaite, 2002; Sell, 2003). The eventual result was the changing of the GATT into the World Trade Organization (WTO), and this radical change can only be understood by keeping in mind how far it arose from US despair about what seemed to them to be the growth of universal unfair competition.

\section{GATT-WTO Differences}

A most important difference between the two sets of international arrangements is the inclusion in the WTO of intellectual property (primarily trade marks, patents and copyright) as well as international trade in services (primarily banking). Hardin's tragedy of the commons is at its most extreme when the resource is information, since physical resources at least exist beforehand even if overuse will destroy them, whereas some kinds of information require a property right if they are even to be brought into existence in the first place. By no means all production of information needs such rights - much information of the highest value has been produced without any economic incentive. But for those types that $d o$ require such an incentive, then, assuming rational investors, absolute freedom to use information, a world without property rights, i.e. an informational commons, could only result in there being no information worth using. Why would anyone invest at high risk to generate it, if others could then take and use it freely? This is why property rights in information, intellectual property, form such an important component of the laws of property that have underwritten the incomparable economic development of the western world (see North \& Thomas, 1973).

\section{The Paris and Berne Conventions}

International arrangements for intellectual property depended upon bilateral agreements between states until 1883, when a convention signed at Paris took their place. The key element in this was a remarkable social invention, the idea of "national treatment". According to this, any signatory country was free to have whatever kind of patent and trade mark laws it wanted, but it agreed to apply these laws indiscriminately to its own citizens and the citizens of other countries which were also members of the convention. In 1886, the Berne Convention introduced similar arrangements for copyright, but the USA did not join and later took the initiative in setting up the rival Universal Copyright Convention.

One problem which the USA faced in the 1980s with these and similar conventions was that they were gentleman's agreements, which appeared to be cynically treated as such by those who were "free-riding" on their intellectual property. There was no compulsion on countries to join-India, for example, built up a formidable indigenous drug industry by keeping out of the Paris Convention. Nor could anything be done about the failure of judicial systems to be even-handed about ownership of intellectual property as between natives and foreigners. In particular, the way in which Japan took all the advantages of membership of the conventions, such as by being able to obtain 
strong trade mark, patent and copyright protection in the USA, whilst giving minimal protection to US firms in return, was particularly damaging and infuriating (see Spero, 1990).

A second problem for the USA was the Secretariat of these conventions. For its first half-century of existence, this naturally acted in the interests of the biggest patent users. After World War II, however, it became a specialized agency of the United Nations (UN) as the World Intellectual Property Organization (WIPO). As such, it increasingly reflected the interests of the many countries (with votes within the UN) which neither needed nor wanted strong intellectual property, rather than the relatively few advanced countries, with the USA at their head, which did.

\section{Imposing Reciprocity}

In the early 1980s, the heads of Pfizer, IBM and Du Pont initiated the Intellectual Property Committee (IPC) to lobby for change in international intellectual property arrangements, in which they were remarkably successful. As Sell put it:

The IPC, in conjunction with its counterparts in Europe and Japan, crafted a proposal based on existing industrialized country laws and presented its proposals to the GATT Secretariat. By 1994, the IPC had achieved its goal in the Trade Related Aspects of Intellectual Property (TRIPS) accord of the Uruguay Round. The United States and ultimately the parties to the GATT negotiations, accepted the particular vision articulated by the IPC. What is new in this case is that industry identified a trade problem, devised a solution, and reduced it to a concrete proposal that it then advanced to governments. These private sector actors succeeded in getting most of what they wanted from an IP agreement, which now has the status of public international law.

(Sell, 2003, p. 96, emphasis added)

A crucial element in the success of this lobbying effort was the splitting of trade policy from general foreign policy. Once this had been done, the United States Trade Representative (USTR) could concentrate on using the country's economic power without reference to factors that the State Department has to take into account, such as defence alliances or foreign public opinion. A characteristic feature of the USTR's behaviour to bring about desired changes abroad thus became the threat (or actuality) of unilateral sanctions.

The ability of the USTR to devise and enforce these was strengthened still further by the enactment of new "Special 301" provisions in the Omnibus Trade and Competitiveness Act of 1988. These overrode GATT complaint and sanction procedures and replaced them by rapid and severe retaliation when US interests were considered to be damaged. They were initially directed particularly at Japan's erosion of the market power of US firms, but were progressively used more widely until eventually the GATT was reconstructed into the WTO.

\section{TRIPS}

It is always easier for interests to capture agencies that operate internationally than those at the national level, because countervailing forces are less well organized (see Olson, 1965). TRIPS (annex 1.c of the Marrakesh Agreement of 15 April 1994, which set up the WTO) sidelines the conventions and WIPO. It effectively means the 
imposition of the US intellectual property system on the entire world, for much of which it is entirely unsuitable. One of the leading US intellectual property lawyers summed up what happened as follows:

The momentum of the multilateral negotiations during the Uruguay Round carried the developed countries well beyond their initial goal, which was to limit the capacity of firms in developing countries to make and export free-riding copies of high-tech goods produced at great cost in the developed countries. Instead, by ... 1991, the developed countries' strategic goal was to impose a comprehensive set of intellectual property standards on the rest of the world.

(Reichman, 1998)

The secondary group of OECD countries all joined WTO, which involves accepting TRIPS as a necessary condition of getting inward foreign investment, especially from multinational high-technology firms. Japan had to move to abandon its protectionist intellectual property policies and procedures. India joined, so taking on the obligation to grant patents to western pharmaceutical firms. Many poor countries agreed to accept the obligations of TRIPS, including enforcement provisions, in exchange for promises of better access to the markets of the rich countries for their agricultural produce and for a few traditional manufactures. Even the poorest of the signatory countries are now being forced to adopt minimum standards of intellectual property law and to promise its enforcement.

\section{Trade Mark Registration}

When intellectual property is thought of, patents come first to mind, but trade marks can be even more economically important, because they give powerful monopolies in brands, and these can be unlimited in time. The market for the psychological ingredient of a product, which is encapsulated in a brand, can only expand from countries with more discretionary income to those with less. Firms in countries with larger home markets have an additional advantage from the acquired experience of their managements in large-scale handling of the special kinds of risk that are associated with decisions about advertising and marketing. Once a country must grant and enforce trade mark registration, therefore, as TRIPS requires, international brands are provided with market power in it through legal monopoly even before they put a product on the market. With all their advantages, nothing can stop these brands from dominating local ones. Any doubt on this point can be resolved by a quick mental comparison of the number of US brands that are strong in Europe and vice versa. The special implications of trade mark registration for the spread of smoking-related diseases in poor countries will be discussed further below.

\section{Reaction Against the WTO}

As a vehicle for increasing world-wide market power, therefore, TRIPS can only result in perpetuating inequality in technology and wealth between the rich and poor countries. Its benefits will be gained by the firms in the advanced countries which are either technologically innovative or owners of major brands. The extension of market power through TRIPS will keep firms in the poor countries out of both economic areas. US scholars who have described the TRIPS aspect of the WTO agreement as "a polite form 
of economic imperialism" (Oddi, 1996) or "imperialistic, outdated and overprotective" (Hamilton, 1996) have done no more than describe the objective reality, and not just the agreement as it is seen by people in poor countries.

From the start of the industrial revolution, every country that has become economically great began by copying: the Germans copied the British, the Americans copied the British and the Germans and the Japanese copied everybody. There should be no illusions about the thrust of TRIPS: it is to ensure that this process of growth by copying and learning by doing will never happen again.

Insult has been added to injury by failure to deliver the access to western markets that the poor countries were promised in exchange for joining the WTO, and subsidized food from the US and the EU continues to damage markets for their native agriculture. The most recent farm Bill in the USA actually increased subsidies, and EU farmers, one of the strongest lobbies of property-owners in the world, continue to block reform of the Union's discredited Common Agricultural Policy. It is no wonder that when the full implications of this began to sink in, world-wide protests against the WTO began and have continued, even to the extent of preventing its ministerial meetings from taking place.

\section{The Pharmaceutical Industry}

It is no coincidence that the consequences of TRIPS are found in an acute form in relation to pharmaceutical products. Success in this industry results from huge amounts of risky investment and, at the same time, drugs need intellectual property more than any other product because of their extreme vulnerability to being copied. What eventually emerges from any drug development process is a formula, certified by public authorities as being safe to use. If this had no patent protection, the cost of setting up production facilities to copy the formula and put it on the market would be an insignificant barrier to competition. Moreover, if the product is effective (which it will be, since it has come through all its clinical trials successfully) the cost of marketing it will not be such as to deter competition.

In contrast, copies of such drugs have to bear no $R \& D$ or testing costs, and can get certification just by proving that they are equally effective. As soon as the famous anti-hypertensive products, Librium and Valium, came off patent, for example, copies could be obtained for only $5 \%$ of their former selling price. Against such a background of risk and reward, there is nothing surprising about the energy with which the pharmaceutical industry lobbies for strong patent protection in rich-country markets, as it did to bring about the 1952 Act in the USA.

It may nevertheless be asked why should its members be equally anxious to obtain patents in countries that are so poor that the markets for pharmaceutical products there cannot be other than very small indeed? The answer is to be found in the nature of the pharmaceutical industry, which is characterized by highly skewed returns to investment in $R \& D$. Eight out of 10 products that are brought to the market do not even return the $R \& D$ investment made in them. Products that do make such a return are to be found in the ninth decile, but it is only in the tenth one that a few "blockbuster" drugs produce returns that are enough to finance a firm's fixed costs together with its losses on failures (Grabowski \& Vernon, 1990). According to research based on access to industry records, it now costs over US $\$ 800$ million to bring a successful drug just to the stage of marketing approval. Only $1 \%$ of projects investigated make it even to clinical trials and, of these, only one in five gets through all testing stages. A new drug with average $R \& D$ costs must therefore earn over US $\$ 400$ million in its best year of a typical 
20-year life cycle to earn a return greater than its cost of capital (DiMasi et al., 2003). Since the actual cost of production of drugs is so low compared with the R\&D and testing costs needed to bring them into being, any marginal revenue the firm may obtain for them from poor countries is almost all profit. In order to maximize this, it seems to be the preferred policy of the international industry to sell a small quantity of a patented drug to the very small number of people who can afford it in these countries.

\section{Generic Drugs}

With such strategies, extension of the western patent system to poor countries exacerbates the problem of access to drugs by the mass of people there. From a detailed survey, Cullet (2003) identified cases "where the implementation of TRIPS directly implies a reduction in access to drugs and thus a step back in the implementation of a right to health". World Health Organization (2002) data show that in Africa HIV/AIDS is the worst killer, followed by malaria; but to treat HIV/AIDS with patented anti-retrovirals can cost between US $\$ 400$ and US $\$ 2500$ a year. The best new medicines against malaria may be 30-200 times more expensive than older drugs, and those for tuberculosis may be 20-30 times more expensive, as long as they are under patent protection.

In these circumstances, the poor countries naturally want access to generic drugs, much cheaper copies of the patented ones, although in many cases even the marginal cost of producing these is more than they can afford. Article 31 of TRIPS permits compulsory licensing of patents in "extreme circumstances", a condition which the AIDS and similar crises in many poor countries surely meet. But section (f) of this article rules that production under a compulsory licence must be "predominantly for the domestic market”. Applied to drugs, this prevents countries such as India, which is able to produce copies of patented drugs, from exporting them, even to countries that have no indigenous production capacity. The WTO Ministerial Conference in Doha in 2001 was prevented by US opposition from agreeing on a waiver of the provisions of article 31, and this opposition was only withdrawn in August 2003 through fear that it would cause the collapse of the conference at Cancún the following month.

Throughout these negotiations, an important factor was the patent-owners' genuine fear that cheap copies would leak into their western markets and reduce their profits there. To meet this, 23 developed countries announced voluntarily that they would not import drugs from countries that used their new freedom to grant compulsory licences. Also, several other countries such as Israel, Korea and Mexico committed themselves to grant such licences "only in emergencies or extremely urgent situations".

\section{Trade Marks and Smoking-related Diseases}

As mentioned earlier, in developed countries trade marks are much more valuable than patents: firstly, because they are the essential basis of brands and the marketing and advertising which support these; secondly, because they grant a true monopoly in these brands; and thirdly, this monopoly is not limited in time, as a patent is. With one important exception, the interest of western firms in trade marks in poor countries is limited because buying branded products requires discretionary income, of which buyers in those countries have very little. Tobacco products are an exception to this lack of interest. Growing public awareness of the links between smoking and a long list of diseases, notably of the lungs and heart, has made developed countries increasingly inhospitable to tobacco firms. As a result, they are now turning their attention to the poorer countries. The fact that under TRIPS these countries must provide them with 
a modern trade mark registration regime means that they can develop brands there through use of the techniques of mass-marketing they understand so well.

The importance of brand advertising to the tobacco firms is shown by the fierce determination they have shown in resisting bans on it in the advanced countries. In the USA, they claimed that any restrictions breached the First Amendment of the Constitution, which guarantees freedom of speech. Everywhere, they argue that advertising has no function in expanding markets, but affects only relative movements of brand shares. This is in fact quite untrue: there is overwhelming evidence that the best way of developing mass markets is in fact competition between brands (see Kingston, 1984, Chapter II).

Consequently, poor countries are now highly vulnerable to a marketing onslaught from the tobacco firms acting to make up losses in advanced-country markets. As a quite inescapable consequence, smoking-related diseases will increase rapidly in these countries. The resulting harmful effect on vital statistics could even counterbalance any victories there may be over HIV/AIDS and malaria, for example.

What is needed in this case is to enable poor countries to deny trade mark registration to products that are not in the public interest, such as by being harmful to health. It could be argued that this would defy article 15.4 of TRIPS, which is that "The nature of the goods or services to which a trade mark is to be applied shall in no case form an obstacle to the registration of the mark". However, this is by no means certain. This article simply carries over a similar provision in the Paris Convention (article 7) and, during the 1958 Lisbon revision of this, Denmark was able to face down an attempt to amend this article so as to challenge its law, which limited the duration of trade marks on pharmaceutical products (Ladas, 1975, pp. 1249-1250).

\section{What can be Done about TRIPS?}

A few drug firms have responded to the poor countries' crisis by giving away particular treatments (see web site www.pqmd.org). These include treatments for river-blindness (Merck), worm-infestation (Glaxo-Smith-Kline), trachoma (Pfizer) and leprosy (Novartis). Other ameliorating initiatives are those by the Gates Foundation in respect of AIDS, and that of the Global Alliance for TB Drug Development (see web site www.tballiance.org). The Gates International AIDS Vaccine Initiative provides grants for development of vaccines for specifically African strains of this disease. Chosen firms may patent any discoveries internationally, but agree to supply the vaccines at marginal cost in developing countries. The Global Alliance is funding a drug firm, Chiron, to develop a new drug for $\mathrm{TB}$, on which no royalties would be charged in these countries. Also, following the delayed Doha agreement on exports of drugs produced through compulsory licensing, the Clinton Foundation has been responsible for an arrangement whereby firms in India and South Africa will provide anti-retroviral drugs to 2 million patients in nine Caribbean and four African countries for only 40 US cents each per day. However greatly such activities are to be welcomed, they can only undo the harm of TRIPS to a very limited degree, since in most of the countries plagued with these diseases, total health-care budgets are from US $\$ 2$ to US $\$ 30$ per person per year. Although the WTO agreement is beginning to be seen as a mistake even in the countries which were responsible for forcing it through (see, e.g. United Nations Development Programme, 2003), the strength of the interests which benefit from it remain strong. They are concerned with getting laws of property shaped to suit them rather than by any concept of the public good, and will work to ensure that the WTO is not dismantled. Their campaign can be expected to claim that any move in that 
direction would be a reversal of the multilateral polices that have been followed since World War II, and which are credited with unprecedented growth of the world economy.

Also, now that TRIPS exists, it is better for the poorer countries that it should be maintained in existence, and reformed. This is because as an instrument of international law, it has the potential to enable them to withstand the power of the USTR in bilateral negotiations. As Cancún showed, when a significant group of these countries act together, they can resist being bullied. Indeed, there are already signs that just as the USA despaired of WIPO and turned to the GATT, it is now despairing of the WTO and turning to bilateral agreements.

In any reform of TRIPS, education of politicians and officials in poor countries on intellectual property matters would be of the greatest importance. These countries signed up to TRIPS in almost complete ignorance of the nature of intellectual property and the consequence of its implications for them. Indeed, one of the reasons why Drahos and Braithwaite wrote their remarkable study of how TRIPS came into being was to urge non-governmental organizations (NGOs) to undertake this task. Some of these have begun to do so, as reflected, for example, in a valuable publications series from the Quaker United Nations Office in Geneva. Work of this kind will do far more to help poor countries obtain whatever positive advantages TRIPS can offer them than protests which make WTO ministerial meetings impossible.

\section{Linking Aid to Intellectual Property}

So much attention has been paid to the evident injustice to poor countries of TRIPS that it is important not to overlook the fact that western patentees do have a case, which is that investment at high risk in generating information cannot be made without anticipation of protection for the results. For example, it would indeed be a serious matter if in spite of the Doha safeguards with respect to compulsory licensing, cheap imports of drugs were to reduce the western firms' level of investment in R\&D. This is self-evident when one thinks of how the virtual elimination of the scourge of tuberculosis in the developed world was due to just one such investment. This was Merck's backing of the research of Selman Waksman, and it led to streptomycin (see Kingston, 2004). The industry has frequently repeated success on a scale which is not far away from this.

Policies for providing aid to poor countries have hitherto been almost completely insulated from policies for trading with them, such as those which brought the WTO into being. Even partial ending of this insulation could offer a way of giving poor countries access to the products they need, without depriving firms in the advanced countries of profits and ability to maintain high levels of R\&D. A proportion of foreign aid funds could be diverted to buying in the intellectual property holdings of western firms in poor countries and redirecting their use in whatever way best improves genuine local industrial development. It would not be a compulsory purchase scheme.

The fact that different levels of management have different objectives has a bearing on this. Once TRIPS is in place, it is the job of those who manage the intellectual property departments of firms to obtain and enforce patents as widely as they can. On the other hand, firms' senior managements, which are concerned with overall and long-term profits, might well be willing to sell patents to an appropriate NGO or similar organization at prices which would not diminish their profits and consequently their ability to finance R\&D. In the drugs case, for example, such sales would clear the way 
for access to drugs by general populations, instead of only by the few people in poor countries who can afford to pay the premium resulting from patent protection.

If the idea worked for patents, then it might eventually be applied to other kinds of intellectual property, such as plant variety or design protection. It is not impossible that in the longer term even trade marks could be dealt with in the same way.

\section{Conclusion}

It is now widely accepted that policies of government-to-government aid have largely failed to meet their objectives. Apart from the waste, much of the money provided has ended up in secret foreign accounts of corrupt politicians from the countries to which it was given. The recent US Millenium Challenge Account and the British International Finance Facility proposals at a meeting of the G8 countries shifted the emphasis fundamentally. They represent acceptance that escape from poverty in the Third World depends upon private enterprise, just as it did in the west. But human creative energy only flows into economic channels if there are appropriate laws of ownership. Intellectual property consequently has a part to play in the economic development of today's poor countries, just as it has contributed to western prosperity. Nothing is more certain, however, than that it will not be intellectual property on the current international model.

The capacity of poor countries to copy advanced technologies is in fact very weak, but is subjectively over-estimated. People in them (and well-meaning people elsewhere who have only superficial knowledge of the topic) may think that all that is stopping them is western-owned intellectual property. In fact, successful imitation requires much more in terms of human and social capital than simply freedom to imitate.

Still, having that freedom is an essential starting point. Allowing poor countries to use and adapt advanced technologies as far as their resources allow is the only way they can begin to learn by doing and failing. The origin of Honda's outstanding and now world-wide engineering capacity, for example, was in the poor wooden copy of the steel looms of Draper's of Lowell and Platts of Oldham, which Seichi Honda made after he saw them at an exhibition in Tokyo in 1889. Yet Honda's firm learned so fast that his automatic looms surpassed theirs within 40 years.

Buying-in of intellectual property as proposed would at least mean that poor countries are not prevented from copying or trying to copy. It therefore appears to have the power to take at least some of the harm out of TRIPS. Of course, this would have to be accompanied by appropriate controls on imports into western countries so that leakage from abroad would not undermine the profits which firms in those countries need for high-risk investment in invention and innovation. It seems likely, however, that the measures that are having to be taken anyway to deal with international terrorism (itself partially fuelled by perceptions of the WTO) will increasingly include controls of this kind.

\section{References}

Buchanan, J.M. \& Tullock, G. (1962) The Calculus of Consent (Ann Arbor, University of Michigan Press).

Cullet, P. (2003) Patents and medicines: the relationship between TRIPS and the human right to health, International Affairs, 79, pp. 139-160.

DiMasi, J.A., Hansen, R.W. \& Grabowski, H.G. (2003) The price of innovation: new estimates of drug development costs, fournal of Health Economics, 22, pp. 151-185.

Drahos, P. \& Braithwaite, J. (2002) Information Feudalism (London, Earthscan). 
Grabowski, H. \& Vernon, J. (1990) A new look at the returns and risks to pharmaceutical R\&D, Management Science, 36, pp. 804-821;

Hamilton, M. (1996) The TRIPS agreement: imperialistic, outdated and overprotective, Vanderbilt Fournal of Transnational Law, 29, pp. 613-634.

Hardin, G. (1968) The tragedy of the commons, Science, 162, pp. 1243-1272.

Kingston, W. (1984) The Political Economy of Innovation (The Hague, Martinus Nijhoff).

Kingston, W. (2000) Antibiotics, invention and innovation, Research Policy, 29, pp. 679-710.

Kingston, W. (2004) Streptomycin, Schatz v. Waksman and the balance of credit for research, Fournal of the History of Medicine and Allied Sciences (forthcoming).

Korten, D. (1995) When Corporations Rule the World (London, Earthscan).

Ladas, S.P. [1930] (1975) Patents, Trademarks and Related Rights: National and International Protection (Cambridge, Harvard University Press).

Mill, J.S. [1862] (1994) Principles of Political Economy, Book II (London, Longman), Chapter I.

Myers, R.A. \& Worm, B. (2003) Fisheries depletion, Nature 423, 15 May, pp. 280-283.

Newman, B.L. (1999) The Mass Marketing of Politics (Thousand Oaks, CA., Sage Publications).

North, D. \& Thomas, R.P. (1973) The Rise of the Western World (Cambridge, Cambridge University Press).

Oddi, A.S. (1996) TRIPS - natural rights and a polite form of economic imperialism, Vanderbilt fournal of Transnational Law, 28, pp. 415-462.

Olson, M. (1965) The Logic of Collective Action: Public Goods and the Theory of Groups (New York, Schocken Books).

Ostrom, E. (1990) Governing the Commons (Cambridge, Cambridge University Press).

Reichman, J.H. (1998) Securing compliance with the TRIPS agreement after US v. India, New York University Fournal of International Economic Law, 1, pp. 585-601.

Rich, J., quoted in Federico, P.J. (1978) Origins of Section 103, in: J.F. Witherspoon (Ed.) Nonobviousness-The Ultimate Condition of Patentability, Sections 1.10, 1.11 (Washington, DC, Bureau of National Affairs).

Sell, S.K. (2003) Private Power, Public Law: The Globalization of Intellectual Property Rights (Cambridge, Cambridge University Press).

Spero, D.W. (1990) Patents or piracy? A CEO looks at Japan, Harvard Business Review, September-October, pp. 58-67.

United Nations Development Programme (2003) Making Global Trade Work for People (UNDP/ Earthscan).

World Health Organization (2002) The selection of essential medicines, WHO Policy Perspectives on Medicines No. 4, June. 


\section{Author Query Sheet}

\begin{tabular}{|l|l|}
\hline \multicolumn{2}{|c|}{ Manuscript Information } \\
\hline $\begin{array}{l}\text { Journal } \\
\text { Acronym }\end{array}$ & cODS \\
\hline $\begin{array}{l}\text { Volume and } \\
\text { issue }\end{array}$ & 32.2 \\
\hline Author name & Kingston \\
\hline $\begin{array}{l}\text { Manuscript } \\
\text { No. (if } \\
\text { applicable) }\end{array}$ & \\
\hline
\end{tabular}

AUTHOR: The following queries have arisen during the editing of your manuscript. Please answer the queries by marking necessary corrections at the appropriate positions on the PROOFS. Do not answer the queries on the query sheet itself. Please also return a copy of the query sheet with your corrected proofs.

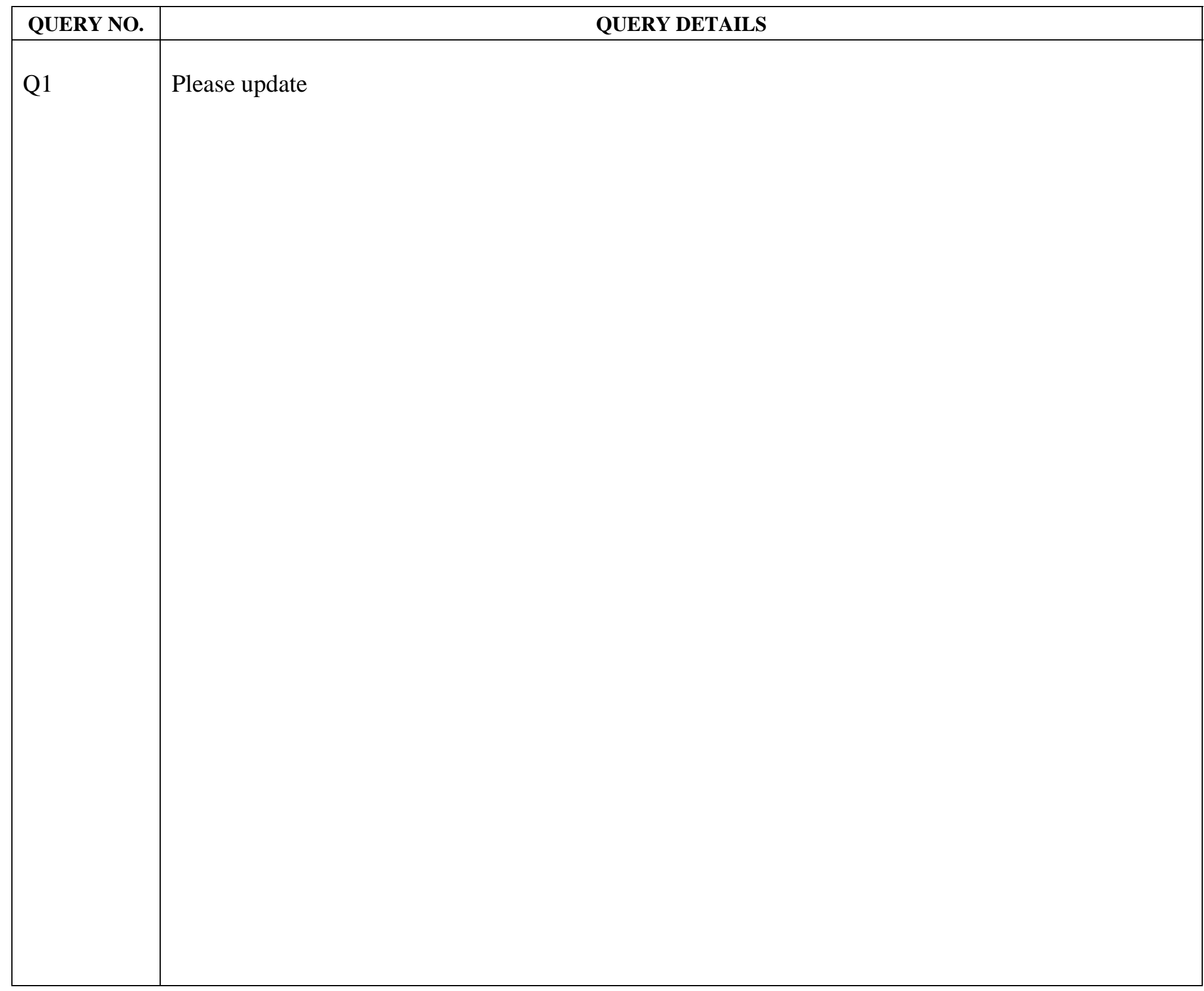

